\title{
Isolation of a lethal rhabdovirus from the cultured Chinese sucker Myxocyprinus asiaticus
}

\author{
Qi-Ya Zhang*, Zhen-Qiu Li, Jian-Fang Gui
}

State Key Laboratory of Freshwater Ecology and Biotechnology, Institute of Hydrobiology, Chinese Academy of Sciences, Wuhan 430072, PR China

\begin{abstract}
A rhabdovirus was found to be associated with a lethal hemorrhagic disease in the cultured Chinese sucker Myхосурrinus asiaticus Bleeker. The rhabdovirus was amplified and isolated from the infected GCO (grass carp ovary) cells. In ultrathin sections of liver cells from the diseased fish, the virus particles exhibited the characteristic bacilliform morphology, and budded through vesicle membranes of the infected cells. The isolated rhabdovirus particles were found to have a bacilliform morphology with 2 rounded ends rather than a typical flat base. The virus particles were measured and ranged in size from 150 to $200 \mathrm{~nm}$ in length and 50 to $60 \mathrm{~nm}$ in diameter. Most other characteristics, including their size, extensive virus infectivity to fish cell lines, strong cytopathogenic effects, stability at high temperatures, vesicle formation in infected cells, structure protein electrophoretic patterns and the presence of an RNA genome, very closely resembled those of other fish rhabdoviruses. At present it is not known if this is a novel virus species or if it is an isolate of a known fish rhabdovirus. Until a confirmed identification can be made, we will temporarily refer to this virus as Chinese sucker rhabdovirus (CSRV).
\end{abstract}

KEY WORDS: Rhabdovirus - Myxocyprinus asiaticus · Fish viral disease - Electron microscopy · Chinese sucker rhabdovirus (CSRV)

\section{INTRODUCTION}

Severe epizootic outbreaks of some lethal diseases occurred in densely stocked fish, frog and turtle ponds, and became factors restricting aquaculture development of special fishery animals in China (Zhang 1997). Recently, several lethal viruses, such as frog iridovirus RGV (Rana grylio virus), penaeid shrimp baculovirus MBV (Penaeus monodon baculovirus), reptile virus TSV (Trionyx sinesis virus), mandarin fish SCSV (Siniperca chuatsi spherical virus), rhabdovirus SCRV and baculovirus SCBV, have been identified and isolated from diseased $R$. grylio (Zhang et al. 1996a, 1999b), from diseased Penaeus orientalis Kishinouxe (Jiang et al. 1995, Zhang et al. 1998), from diseased soft-shelled turtle Trionyx sinensis (Zhang et al. 1997, 1999a) and from diseased mandarin fish S. chuatsi (Zhang et al. 1996b, Zhang \& Li 1999). These various species of

*E-mail: jfgui@ihb.ac.cn viruses have also been demonstrated to be associated with serious disease outbreaks in a number of aquaculture animals in other parts of the world (Wolf 1988, Ahne et al. 1997, Lightner \& Redman 1998, Munday \& Owens 1998, Nakajima et al. 1998, Rodgers \& Furones 1998, Sohn \& Park 1998).

Chinese sucker Myхосурrinus asiaticus Bleeker is a rare species of fish, and belongs to the family Catostomidae of Cypriniformes. Most species in this family are distributed in North America, and only 1 species, the Chinese sucker, is found in Asia. This Chinese sucker was recently listed in the China Red Data Book of Endangered Animals (Yue \& Chen 1998). Because of its long dorsal fin and beautiful body color, the species has been propagated and cultured as an ornamental fish. From June to October 1998, a previously undescribed infectious and lethal disease was observed in the cultured Chinese sucker. The affected fish showed typical symptoms such as hemorrhage. Examination of the diseased fish failed to reveal pathogenic bacteria or parasitic agents infecting these fish. This suggested 
that the disease might be related to viral infection. We therefore collected diseased fish showing typical symptoms and made an attempt to isolate the virus. Through a series of observations and analysis, a rhabdovirus was identified as the pathogen associated with the disease of sucker fish. Here, we report the isolation process of the rhabdovirus.

\section{MATERIALS AND METHODS}

Processing of diseased fish samples. A total of 35 diseased juveniles were collected from the diseased population cultured in one pond. These juveniles, weighing about 5 to $10 \mathrm{~g}$, were used to prepare tissue extracts. Liver, spleen, kidney and muscle were sampled from the diseased fish. The samples were ground in a mortar and diluted 1:10 in phosphate buffered saline (PBS) containing antibiotics (100 IU penicillin $\mathrm{ml}^{-1}, 100 \mu \mathrm{g}$ streptomycin $\mathrm{ml}^{-1}$ ). The extract was stored overnight at $-20^{\circ} \mathrm{C}$. Then, the supernatant was collected by centrifugation at $2000 \times g$, and filtered through a 300 to $450 \mathrm{~nm}$ filter membrane. The filtered supernatant was used as the viral isolate for infecting cell lines, and stored at -80 or $-20^{\circ} \mathrm{C}$.

Cell lines to be used. A total of 8 cell lines, including GCK (grass carp kidney), FHM (fathead minnow), CAB (Carassius auratus blastula embryos), CLC (leucocytes of common carp), EPC (epithelioma papulosum cyprini), GCO (grass carp ovaries), GCF (grass carp fins), and GRO (Gobiocypris rarus ovary), were used for viral sensitivity tests (Zhang 1997). The cells were grown in TC 199 medium with $10 \%$ fetal bovine serum and antibiotics (100 IU penicillin $\mathrm{ml}^{-1} ; 100 \mu \mathrm{g}$ streptomycin $\mathrm{ml}^{-1}$ ). The growth temperature was $25^{\circ} \mathrm{C}$ unless otherwise stated.

Cell infection and virus titration. After the stored isolate had been thawed at room temperature, serial 10 -fold dilutions of the isolate, from $10^{-1}$ to $10^{-8}$, were inoculated onto culturing cells in 96-well plates as previously described (Zhang et al. 1996a). The virus titration was measured on the basis of $\mathrm{TCID}_{50} \mathrm{ml}^{-1}$ as described by Reed \& Muench (1938).

Effect of culture temperature on virus replication. Monolayer cultures of GCF or GCO cells were prepared in 96-well microplates and inoculated with the virus at multiplicity of infection $(\mathrm{MOI})=1$. After $1 \mathrm{~h}$ adsorption, cells were washed with PBS buffer and TC 199 medium was then added. The cultures were incubated at $15,20,25$ and $30^{\circ} \mathrm{C}$. At $5 \mathrm{~d}$ post-inoculation, the virus infectivity in each microplate was determined.

Effect of 5-iododeoxyuridine (IUdR) on virus replication. Monolayer cultures of GCO cells in multi-well plates were first exposed to $10^{-2}, 10^{-3}$ and $10^{-4} \mathrm{mg} \mathrm{ml}^{-1}$
IUdR for $12 \mathrm{~h}$. Afterwards, the cultures were titrated for their virus content using the $\mathrm{TCID}_{50}$ method. A known DNA virus, frog iridovirus (Zhang et al. 1999b), served as the positive control, and a known RNA virus, the hemorrhagic virus of grass carp (Chen \& Jiang 1984), served as the negative control. The cultures were respectively infected with the 3 viruses, incubated at $25^{\circ} \mathrm{C}$ for $10 \mathrm{~d}$, and the effect of IUdR on viral replication was determined by the method of Rovozzo \& Burke (1973).

Heat lability. In order to determine if the virus agent was sensitive to heat, the virus isolate was titrated after exposure to water baths maintained at 50 or $56^{\circ} \mathrm{C}$ for $60 \mathrm{~min}$, or at 60 or $65^{\circ} \mathrm{C}$ for $30 \mathrm{~min}$. The remaining virus infectivity was measured.

Chloroform sensitivity. The virus isolate was mixed with an equal volume of chloroform, then the mixtures were shaken for $10 \mathrm{~min}$ and centrifuged at $3000 \times g$ for $10 \mathrm{~min}$ to separate the chloroform from the aqueous phase of the treated sample, diluted in serial 10-folds, and the dilutions were inoculated onto GCO cells. The virus infectivity in treated and control (no treatment with chloroform) samples were titrated to determine if the virus possessed a lipid-containing envelope.

Stability at pH levels. Stability at selected $\mathrm{pH}$ levels, from $\mathrm{pH} 2$ to 8.5 , was tested by incubating the virus isolate in TC 199 medium adjusted to each $\mathrm{pH}$ by the addition of $0.1 \mathrm{~N} \mathrm{HCl}$ or $0.1 \mathrm{~N} \mathrm{NaOH}$. After $2 \mathrm{~h}$ incubation at $25^{\circ} \mathrm{C}$, the virus infectivity was titrated as compared to the control (no treatment).

Isolation and purification of virus. Stock virus suspensions were prepared by propagating virus isolate in GCO cells using TC 199 medium supplemented with $10 \%$ fetal bovine serum for cell growth and maintenance in $25^{\circ} \mathrm{C}$. Following complete development of cytopathic effect (CPE), cell culture fluids were harvested and cell debris removed by centrifugation at $8000 \mathrm{rpm}(7000 \times g)$ for $20 \mathrm{~min}$, the supernatant was ultracentrifuged in a Beckman (rotor type, SW41) at $38000 \mathrm{rpm}(90000 \times g)$ for $40 \mathrm{~min}$. The pellet was resuspended in $1 \mathrm{ml}$ PBS and further purified by using discontinuous sucrose $(20,30,40$ and $50 \%)$ gradient centrifugation at $38000 \mathrm{rpm}(90000 \times g)$ for $40 \mathrm{~min}$. The virus particle band was collected, and sucrose was removed by centrifugation again. The resulting pellet was resuspended in TE buffer, and this purified virus was stored at $-20^{\circ} \mathrm{C}$. The purified viruses were used for electron microscopy observation.

Electron microscopy. The liver of the diseased fish was fixed with $2 \%$ glutaraldehyde, post-fixed in osmium tetroside $\left(\mathrm{OsO}_{4}\right)$, dehydrated and embedded. Ultrathin sections were cut and stained with $2 \%$ uranyl acetate and lead citrate, then examined with an Hitachi H-7000 transmission electron microscope. The purified virus samples were negatively stained with $2 \%(\mathrm{w} / \mathrm{v})$ 
uranyl acetate and examined under an Hitachi H-7000 transmission electron microscope.

Electrophoresis of virus structure polypeptides. The purified virus was dissolved in loading buffer $(50 \mathrm{mM}$ Tris-Cl [pH 6.8], $100 \mathrm{mM}$ dithiothreitol, $2 \%$ SDS, $0.1 \%$ bromophenol blue, $10 \%$ glycerol) and boiled at $100^{\circ} \mathrm{C}$ for $5 \mathrm{~min}$. Polypeptides were separated by sodium dodecyl sulphate $15 \%$ polyacrylamide gel electrophoresis (SDS-PAGE) on Mini-Protein II electrophoresis system (BioRad) described previously (Gui et al. 1994). The bands were visualized using Coomassie brilliant blue.

Determination of virus nucleic acid. $200 \mu \mathrm{g} \mathrm{ml} \mathrm{g}^{-1}$ Proteinase $\mathrm{K}$ and $1 \%$ SDS were added to the resuspended purified virus. After incubation for $1 \mathrm{~h}$ at $37^{\circ} \mathrm{C}$, the viral nucleic acid was extracted with equal volume of saline-saturated phenol-chloroform (1:1) and chloroform. Then, the aqueous phase was precipitated with 2.5 volumes cold

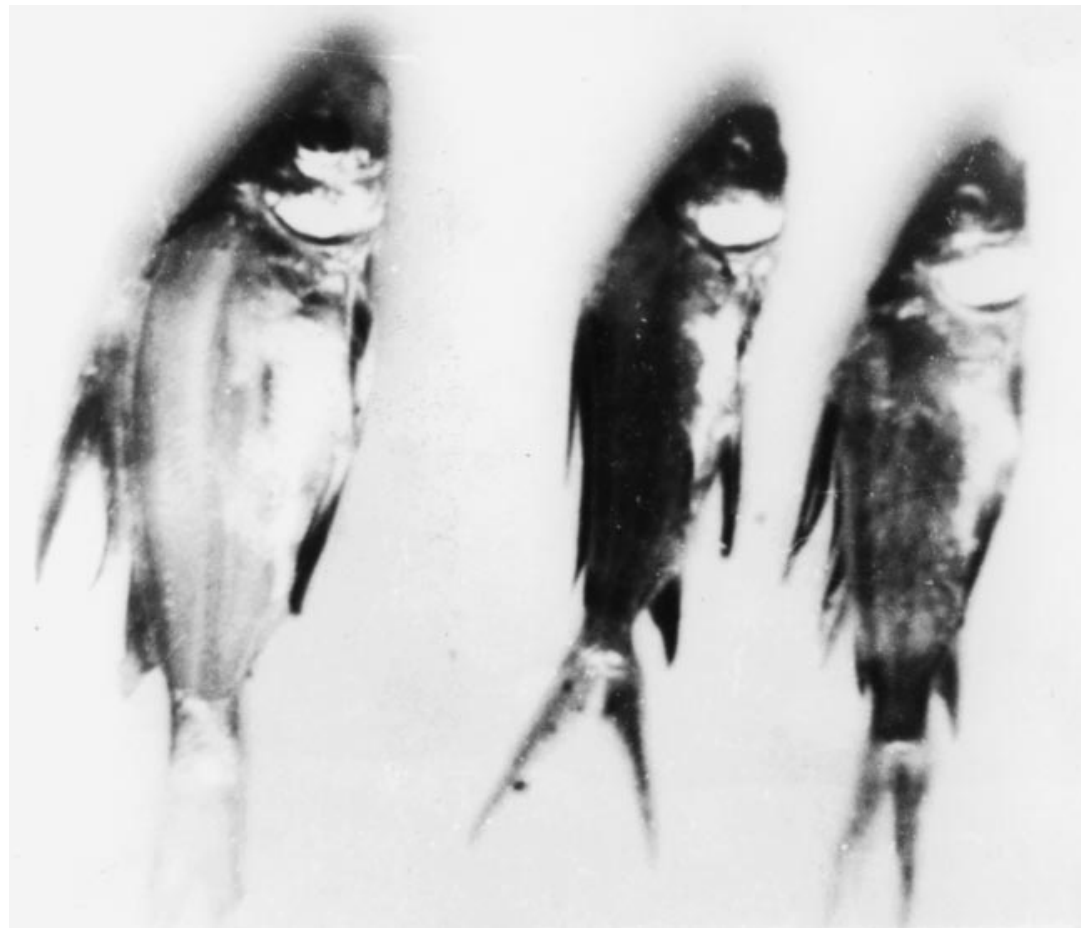

Fig. 1. Rhabdovirus infecting Myхосyprinus asiaticus. Healthy control fish (left) and diseased fish with severe hemorrhage symptoms (right). The skins have been removed from these fish
$\mathrm{NaCl}$, and stored at $-20^{\circ} \mathrm{C}$ for $2 \mathrm{~h}$ or

$-80^{\circ} \mathrm{C}$ for $20 \mathrm{~min}$. The nucleic acids were pelleted by centrifugation at $15000 \mathrm{rpm}(15000 \times \mathrm{g})$ for $15 \mathrm{~min}$. The pellet was finally resuspended in TE (1 mM EDTA, 10 mM Tris-Cl, pH 8.0).

The viral nucleic acid was treated with DNase I and RNase A respectively $\left(1 \mu \mathrm{g} \mathrm{ml} \mathrm{m}^{-1}\right)$ at $37^{\circ} \mathrm{C}$ for $30 \mathrm{~min}$. Then, the treated samples and control sample without treatment were electrophoresed together with molecular weight standards on $0.8 \%$ agarose (TBE) at $50 \mathrm{~V}$ for $2 \mathrm{~h}$. The gel was then stained with ethidium bromide, and visualized and photographed under UV illumination.

\section{RESULTS}

\section{Symptoms of the diseased fish}

Poor appetite and abnormal swimming were the first signs of the disease. At first, a few of the sucker juveniles in the fish pond raised their heads over the water to breathe. After several days, the symptoms became more extensive and severe, and could not be alleviated by bactericides and antibiotics. Eventually, almost of all of the fish in the fish pond were infected, and the diseased fish died. Severe hemorrhage in the muscle was obvious when the skin of the diseased fish was removed (Fig. 1), and numerous hemorrhage spots on the liver and other tissues could be observed after dissection.

\section{Cellular distribution and morphology of the virus in liver cells of diseased fish}

Numerous virus particles were observed by electron microscopy of ultrathin sections of liver cells from the diseased fish. The virus particles were usually crowded together, and had clustered into several large vesicles. Fig. 2A shows an electron micrograph with 2 large vesicles full of virus particles from one section of an infected liver cell. Four to 5 of the large vesicles were also observed in 1 cell in some sections. The data indicated that the vesicles might be viral inclusion bodies revealed by staining with haematoxylin and eosin (data not shown) and that there might be numerous viral inclusion bodies in a single infected cell. The viruses are bacilliform-shaped, and enveloped virions. They are apparently formed by budding from intracellular membranes of the vesicles. Therefore, the virions around the vesicles were mostly bacilliform-shaped when a longitudinal section was cut, whereas the viri- 

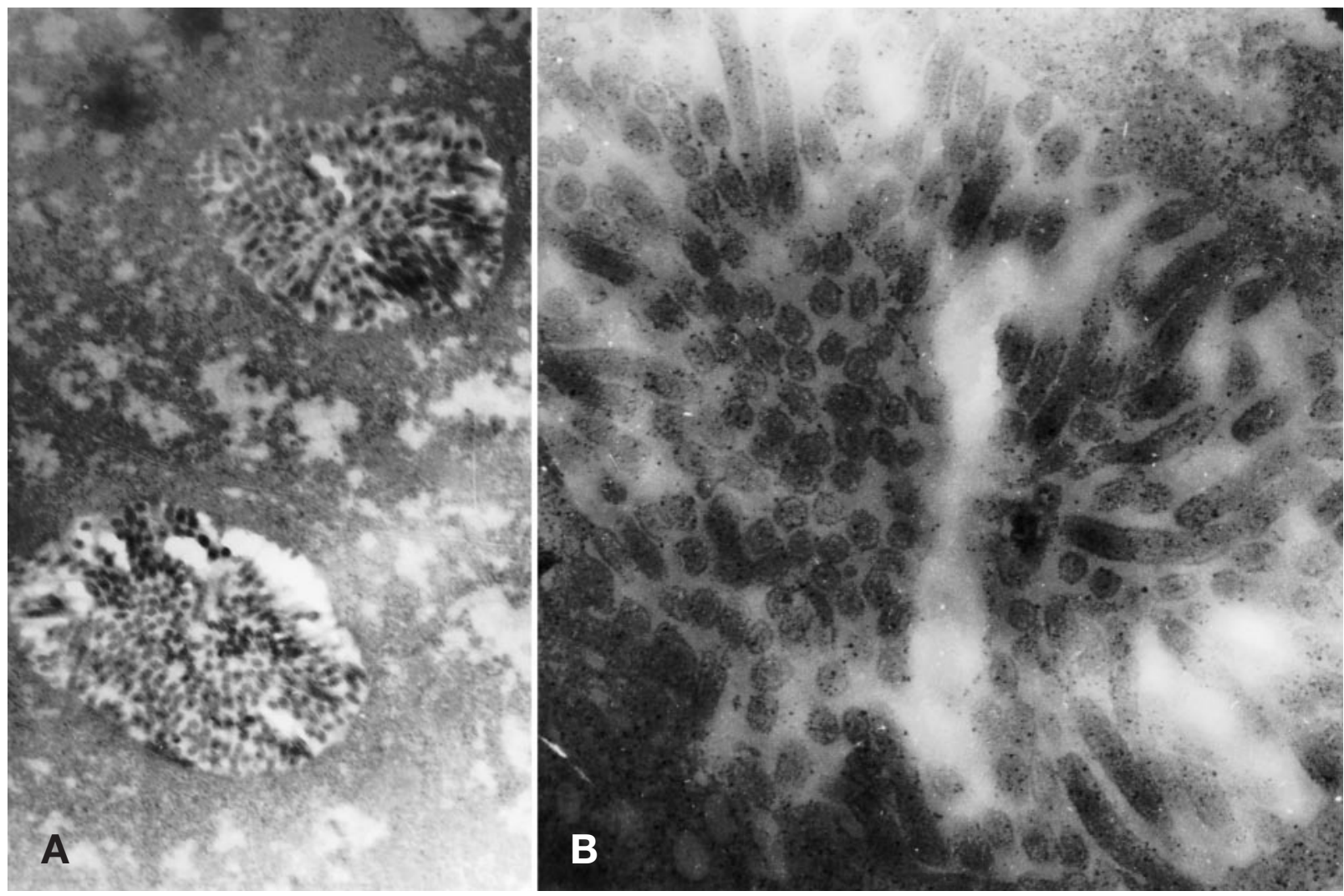

Fig. 2. Rhabdovirus infecting Myxocyprinus asiaticus. Electron micrographs of an infected liver cell from a diseased fish. (A) Two large vesicles full of numerous bacilliform viruses; $\times 15$ 000. (B) Enlarged micrograph of 1 vesicle. $\times 45000$

ons in the center generally had an circular shape when a cross section was cut (Fig. 2B). They were tightly enclosed within the vesicles. Their length varied greatly, ranging from 100 to about $600 \mathrm{~nm}$, but the width was uniform, about 50 to $60 \mathrm{~nm}$.

\section{CPEs induced by the isolate}

The isolate of diseased fish induced typical cytopathogenic effects in 7 cell lines from the 8 fish cell lines examined (Fig. 3). CPEs were observed in all cell lines but one, namely GRO. Some differences in the cytopathogenic appearance of the 7 cell lines infected under the same conditions could be observed. In GCF, GCO, EPC, FHM and CIK, obvious CPEs

Table 1. Infectivity of the isolate in the selected 8 fish cell lines

\begin{tabular}{|ccccccccc|}
\hline \multicolumn{8}{c|}{ Cell line } \\
& GCO & GCF & EPC & FHM & CIK & CAB & CLC & GGO \\
\hline TCID $_{50}$ & $10^{5.8}$ & $10^{5.8}$ & $10^{6.2}$ & $10^{5.5}$ & $10^{5.0}$ & $10^{4.5}$ & $10^{4.5}$ & 0 \\
\hline
\end{tabular}

were observed in cell monolayers after 1 to $2 \mathrm{~d}$ incubation at $25^{\circ} \mathrm{C}$, and the entire cell sheets were almost completely lysed after $1 \mathrm{wk}$. In $\mathrm{CAB}$ and CLC, the isolate showed moderate infectivity, and CPEs were observed in the cell monolayers until 2 to $3 \mathrm{~d}$ incubation at $25^{\circ} \mathrm{C}$. The susceptibilities and CPEs produced in 7 fish cell lines are summarized in Table 1 and Fig. 3. The data indicated that viruses are present in the isolate.

\section{Effect of temperature on infectivity}

Monolayers of GCO and GCF cell cultures were infected with 10 -fold dilutions of the tissue isolate at $15,20,25$ and $30^{\circ} \mathrm{C}$ respectively. The proliferation rate of the virus in GCO cells was found to increase as the incubation temperature increased from 15 to $30^{\circ} \mathrm{C}$. The maximum virus infectivity was obtained with $\mathrm{TCID}_{50}$ $10^{5.8}$ at $30^{\circ} \mathrm{C}$, and the minimum virus infectivity was obtained with $\mathrm{TCID}_{50} 10^{2.5}$ at $15^{\circ} \mathrm{C}$. The proliferation rate of the virus in GCF cells was similar to that of GCO cells at 25 and $30^{\circ} \mathrm{C}$, but the virus did not replicate in GCF cells at $15^{\circ} \mathrm{C}$ (Fig. 4). 


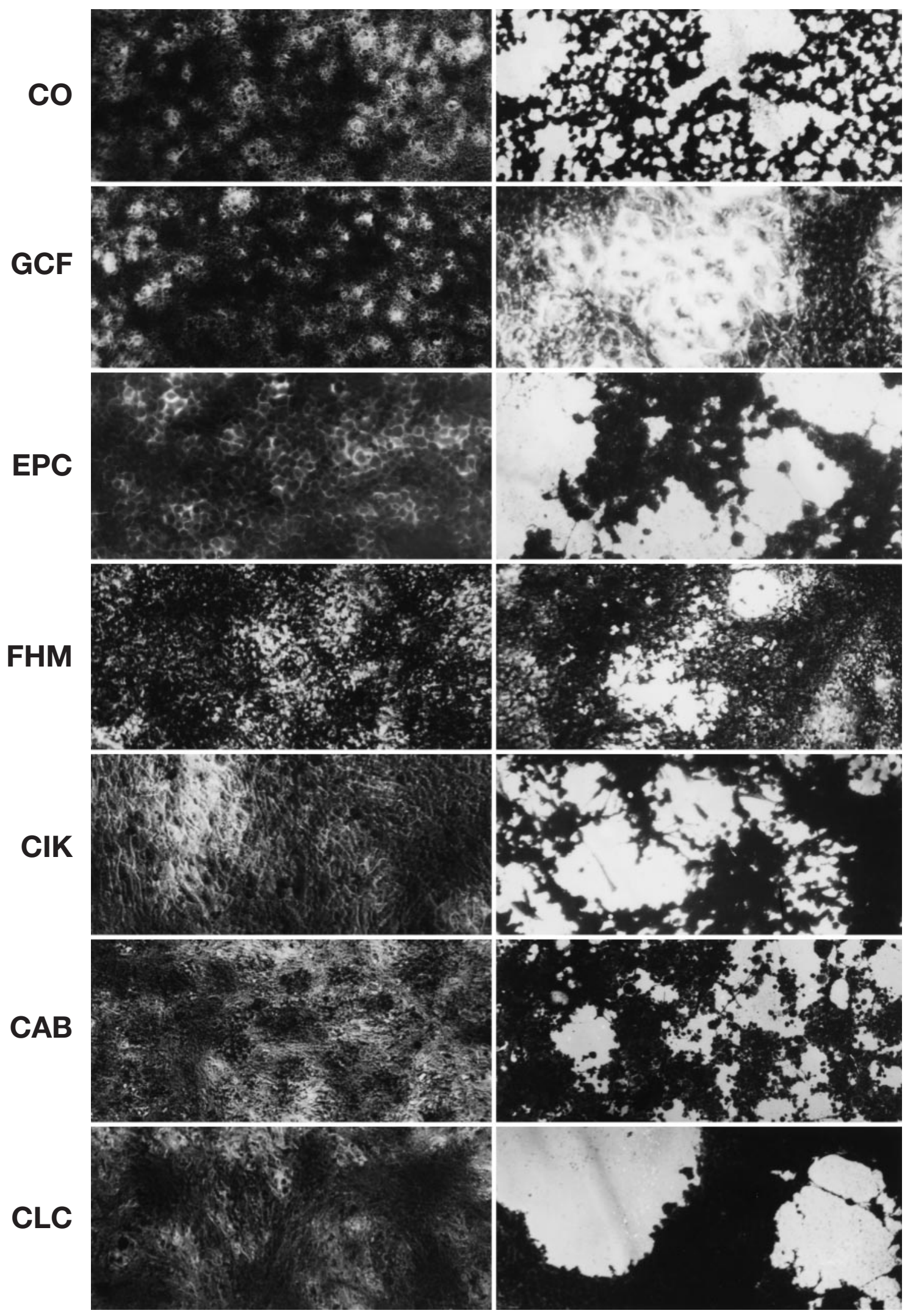

Fig. 3. Plaque characteristics of cytopathogenic effects in the infected 7 cell lines (CO, GCF, EPC, FHM, CIK, CAB and CLC). Left: uninfected control cultures; right: infected cells with cytopathogenic effects. $\times 25$ 


\section{Partial biochemical and biophysical characteristics}

The deoxyuridine analogues IUdR and chloroform were used to treat the isolate. It was found that IUdR did not affect infectivity of the virus. The proliferation of the reference RNA virus, the hemorrhagic virus of grass carp, was also not affected by the presence of IUdR in the medium. In contrast, the positive control DNA virus, frog iridovirus, was completely inhibited by the presence of IUdR. Chloroform treatment did reduce infectivity of the isolate. Infectivity caused significant reduction at $\mathrm{pH} 2$ and 3, but treatment at

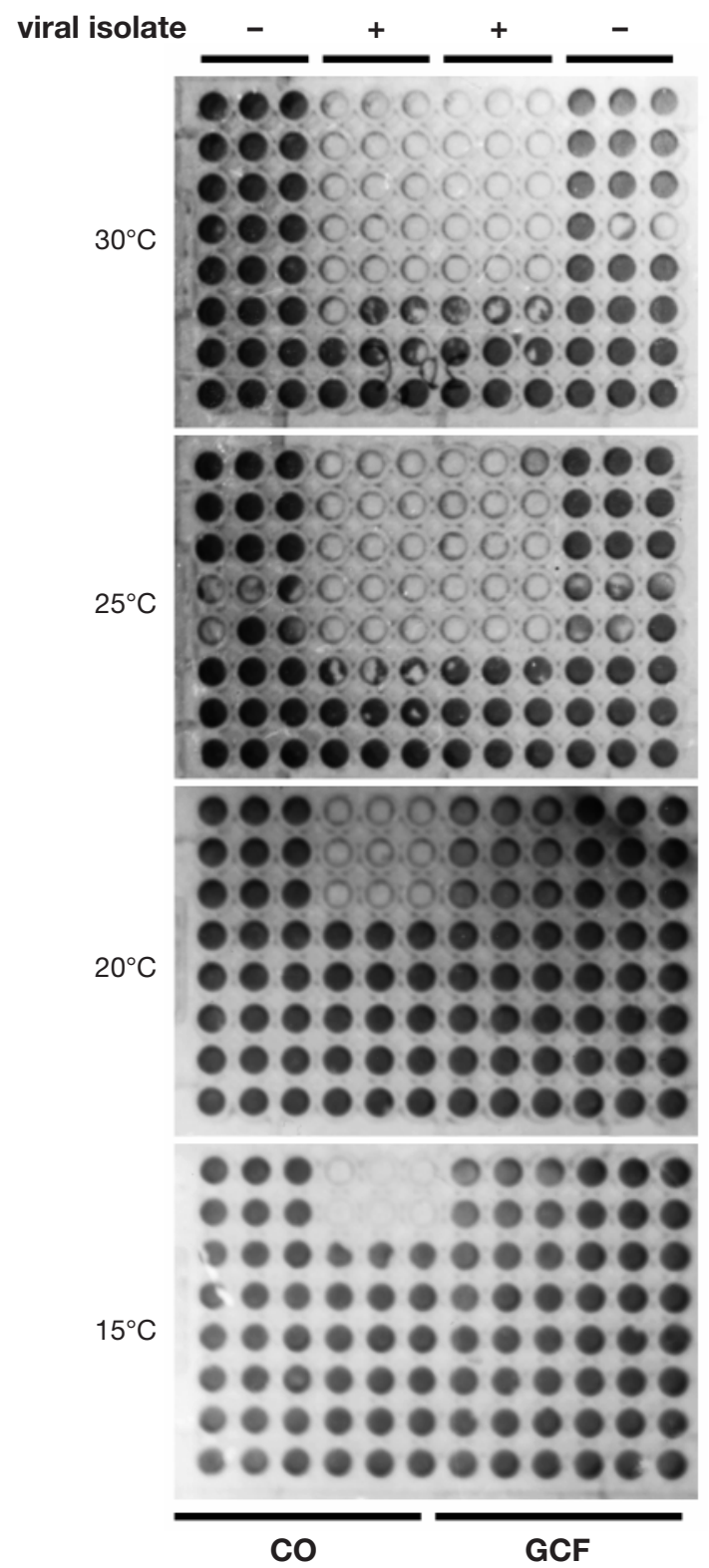

Fig. 4. Comparative results of $\mathrm{CPE}$ occurring in $\mathrm{CO}$ and GCF cells infected with 10 -fold diluted isolates at 4 different culture temperatures
$\mathrm{pH} 8.5$ showed no effects on viral infectivity. Additionally, the virus was stable at high temperatures, i.e. maintenance at $56^{\circ} \mathrm{C}$ for 60 min did not reduce infectivity. A reduction in infectivity occurred at $60^{\circ} \mathrm{C}$ or more. These results, summarized in Table 2, indicate that the virus possesses a possible RNA genome and a lipid-containing envelope.

\section{Isolation and purification of the virus}

The viruses were isolated and purified by sucrose gradient centrifugation from GCO cells infected by the virus isolate. Electron microscopy observations revealed that the negatively stained virus particles had a bacilliform morphology with 2 rounded ends rather than a typical flat base like most of other fish rhabdoviruses (Fig. 5). The particles were measured and ranged in size from 150 to $200 \mathrm{~nm}$ in length and 50 to $60 \mathrm{~nm}$ in diameter.

\section{Analysis of the viral structural proteins}

SDS-PAGE analysis of the purified virus particles indicated that the structural proteins were mainly composed of 7 polypeptides with the following estimated molecular weights: $16,50,60,68,85,100$ and $140 \mathrm{kDa}$ (Fig. 6). The 2 polypeptides of 60 and $68 \mathrm{kDa}$ might be the main structural proteins of the rhabdovirus.

\section{Analysis of the viral nucleic acid}

Agarose gel electrophoresis of the viral nucleic acid extracted from the purified viruses revealed a band approximately $14 \mathrm{~kb}$ in size, when estimated by extrapolation from DNA markers (Fig. 7). When the nucleic acid was digested with DNase I or RNase A, it was found that the viral genome was sensitive to

Table 2. Viral titres after treatments with IUdR, chloroform, different $\mathrm{pHs}$ and at high temperatures

\begin{tabular}{|ll|}
\hline Treatment & TCID $_{50} \mathrm{ml}^{-1}$ \\
\hline Untreated (normal control) & $10^{5.8}$ \\
IUdR & $10^{5.8}$ \\
Chloroform (50\%) & 0 \\
pH 2 (60 min) & $10^{1.2}$ \\
pH 3 (60 min) & $10^{2.5}$ \\
pH 8.5 (60 min) & $10^{5}$ \\
$50^{\circ} \mathrm{C}(60 \mathrm{~min})$ & $10^{5.8}$ \\
$56^{\circ} \mathrm{C}(60 \mathrm{~min})$ & $10^{5.5}$ \\
$60^{\circ} \mathrm{C}(30 \mathrm{~min})$ & $10^{1.7}$ \\
$65^{\circ} \mathrm{C}(30 \mathrm{~min})$ & 0 \\
\hline
\end{tabular}




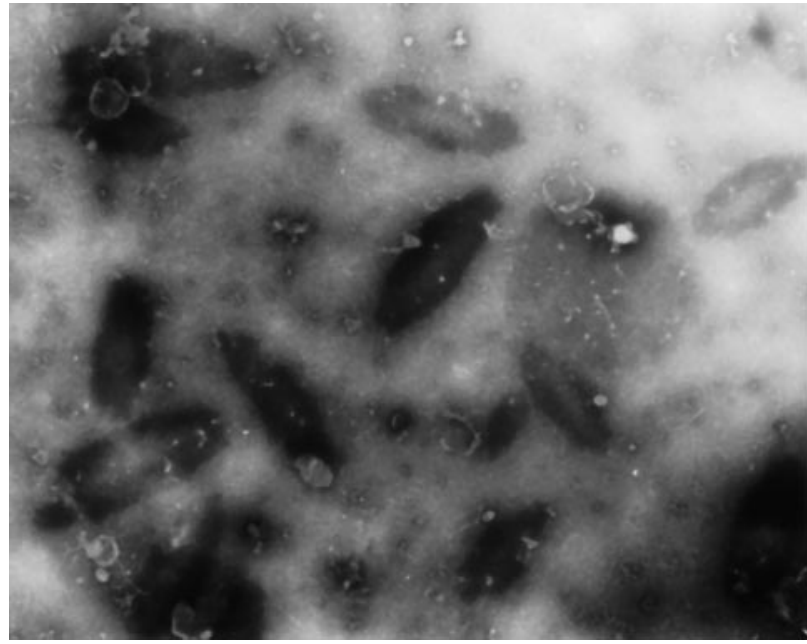

Fig. 5. Negatively stained virions isolated from infected CO cells. $\times 40000$

RNase digestion, but the nucleic acid band did not change when treated with DNase I (Fig. 7). The data confirmed that the rhabdovirus is a typical RNA genome virus.

\section{DISCUSSION}

The virus described here was isolated from the cultured Chinese sucker Myхосурrinus asiaticus with a lethal hemorrhage disease. The morphology and char-

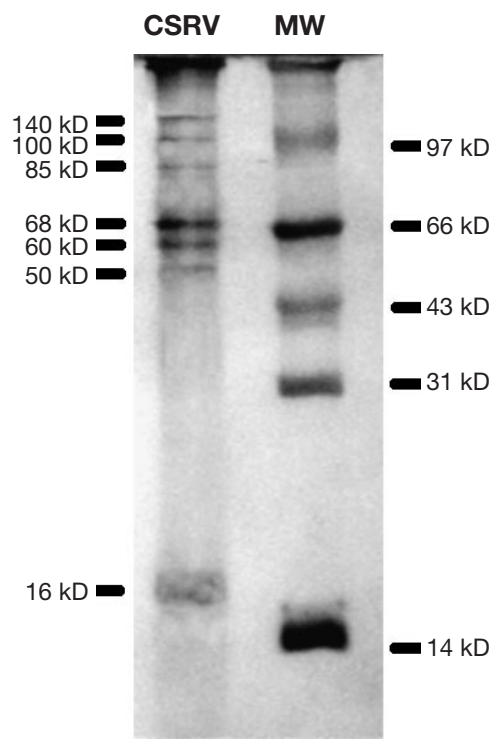

Fig. 6. Structural proteins of the rhabdovirus. The 7 structural protein bands are indicated on the left; standard molecular weight (MW) markers shown on the right. CSRV: Chinese sucker rhabdovirus

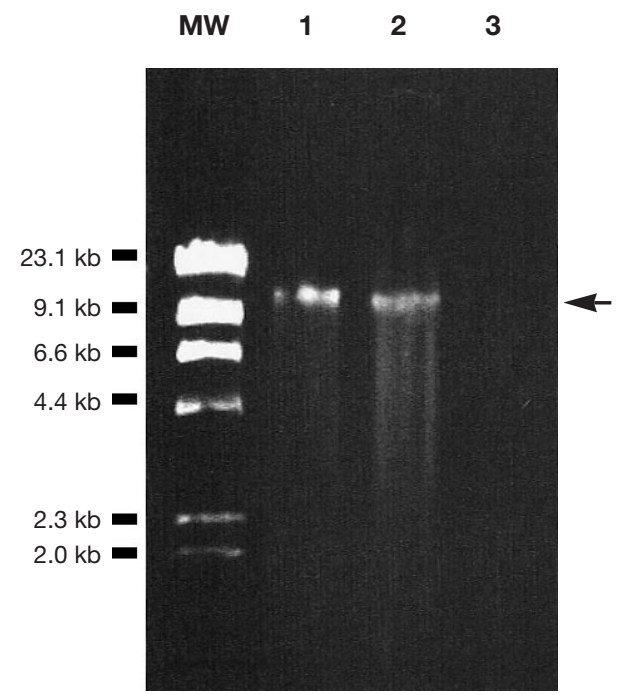

Fig. 7. RNA genome confirmation of the rhabdovirus. The standard molecular weight (MW) DNA markers, the extracted nucleic acid (lane 1), the nucleic acid sample treated with DNase I (lane 2), and the nucleic acid sample treated with RNase A (lane 3) were electrophoresed in agarose gel as described in 'Materials and methods'. Arrow indicates position of the rhabdovirus RNA band

acterization of the viral particles suggested that the isolated virus should be a member of the Rhabdoviridae (Murphy et al. 1995). For example, in the ultrathin sections of liver cells from the diseased fish, the virus particles exhibited a characteristic bacilliform morphology, and budded through the vesicle membranes of the infected cells like the other rhabdoviruses (Kasornchandra et al. 1992, Lilley \& Frerichs 1994, Granzow et al. 1997). The negatively stained virus particles that were isolated from the infected cells were found to have 2 rounded ends rather than a typical flat base, just like shuttles. A similar morphology was also described by Kasornchandra et al. (1991) in snakehead rhabdovirus (SHRV). Moreover, most of the characteristics of these virus particles, including their size, extensive virus infectivity to fish cell lines, strong CPEs, stability at high temperatures, vesicle formation in infected cells, and a possible RNA genome, very closely resemble those of other rhabdoviruses (Wolf 1988, Frerichs 1989, Kasornchandra et al. 1991, 1992, Lilley \& Frerichs 1994, Granzow et al. 1997). Generally, the rhabdoviruses contain a single-strand RNA molecule about 11 to $15 \mathrm{~kb}$ in size, and have 5 main structural polypeptides (Murphy et al. 1995). SDS-PAGE analysis of the virus particles revealed some differences from typical rhabdovirus with respect to the size of the structural polypeptides, but 60 and $68 \mathrm{kD}$ main structure polypeptides were similar to the structural glycoproteins of other rhabdoviruses. Agarose gel electrophoresis of the viral nucleic acid extracted from the 
purified virus particles indicated that the virus contains a typical rhabdovirus RNA genome. At present it is not known if this is a novel virus species or if it is an isolate of a known fish rhabdovirus. Until a confirmed identification can be made we will temporarily refer to this virus as Chinese sucker rhabdovirus (CSRV).

Rhabdoviruses are significant virus pathogens in aquaculture, and more than 10 species of rhabdoviruses, such as viral haemorrhagic septicemia virus (VHSV) (Jensen 1963), infectious haematopoietic necrosis virus (IHNV) (Amend et al. 1969), spring viraemia of carp virus (SVCV) (Fijan et al. 1971) or rhabdovirus carpio (Shchelkunov \& Shchelkunova 1989) pike fry rhabdovirus (PFRV) (de Kinkelin et al. 1973), eel virus A (EVA) (Sano 1976), eel virus Europe X (EVEX) (Sano et al. 1977), cod ulcus-syndrome rhabdovirus (Jensen et al. 1979), Rio Grande perch rhabdovirus (Malsberger \& Lautenslager 1980), eel virus B (Castric \& Chastel 1980), rhabdovirus salmonis (Osadchaya \& Nakonechnaya 1981), perch rhabdovirus (Dorson et al. 1984), hirame rhabdovirus (HRV) (Kimura et al. 1986), ulcerative disease rhabdovirus (UDRV) (Frerichs et al. 1986) and snakehead rhabdovirus (SHRV) (Kasornchandra et al. 1991) have been isolated from cultured fish. The infected fish include some important freshwater and marine species, for example, rainbow trout, common carp and Japanese flounder, and these rhabdoviruses have caused great economic losses. It has been demonstrated that the recent population decline of pacific herring Clupea pallasi in Prince William Sound, Alaska, USA, is related to a rhabdovirus (VHSV) infection (Meyers et al. 1994, Meyers \& Winton 1995, Marty et al. 1998). In cultured penaeid shrimp, the yellow-head virus (YHV) that caused massive losses in Thailand and elsewhere throughout Asia was initially described as a baculovirus, but was recently reclassified as a rhabdovirus (Nadala et al. 1997). Additionally, a yellow-head-like virus was also found to be associated with mortalities of cultured Penaeus monodon in Australia (Spann et al. 1997).

Most fish rhabdoviruses have been analyzed and compared in terms of their morphology, cytopathogenicity, serological relatedness and structural polypeptide composition (Ahne et al. 1988, Frerichs 1989, Kasornchandra et al. 1991, 1992, Lilley \& Frerichs 1994, Granzow et al. 1997). Recently, reverse transcriptase-polymerase chain reaction (RT-PCR) assay has been developed and applied to detecting fish rhabdovirus IHNV and VHSV in fixed and embedded fish tissue by Chiou et al. (1995) and in organ samples and cultured cells by Miller et al. (1998). Accordingly, we are seeking to develop some molecular methods (Leong 1995) to make comparisons of the CSRV and other fish rhabdoviruses and to provide useful biological tools for detecting fish rhabdovirus pathogens.
Acknowledgements. This research was supported by grants from the Major State Basic Research Program (No. G1999053908) of the People's Republic of China, the State Key Laboratory of Freshwater Ecology and Biotechnology, the Chinese Academy of Sciences, Hubei Natural Science Foundation and the National Natural Science Foundation of China. We thank Drs Jian-Bo Chang and Jian-Wei Wang for helping to collect the diseased fish samples.

\section{LITERATURE CITED}

Ahne W, Lorgensen PEV, Olesen NJ, Wattanavijarn W (1988) Serological examination of a rhabdovirus isolated from snakehead (Ophicephalus striatus) in Thailand with ulcerative syndrom. J Appl Ichthyol 4:194-196

Ahne W, Bremont M, Hedrick RP, Hyatt AD, Whittington RJ (1997) Iridoviruses associated with epizootic haematopoietic necrosis (EHN) in aquaculture. World J Microbiol Biotechnol 13:367-373

Amend DF, Yasutake WT, Mead RW (1969) A haematopoietic virus disease of rainbow trout and sockeye salmon. Trans Am Fish Soc 98:796-804

Castric J, Chastel C (1980) Isolation and characterization attempts of three viruses from European eel, Anguilla anguilla: preliminary results. Ann Virol (Inst Pasteur) 131E:435-448

Chen Y, Jiang Y (1984) Morphological and physico-chemical characterization of the hemorrhagic virus of grass carp. Kexue Tongbao (Chin Sci Bull) 29:832-835

Chiou PWP, Drolet BS, Leong JC (1995) Polymerase chain amplification of infectious hematopoietic necrosis virus RNA extracted from fixed and embedded fish tissue. J Aquat Anim Health 7:9-15

de Kinkelin P, Galimard B, Bootsma P (1973) Isolation and identification of the causative agent of 'red disease' of pike (Esox lucius L.). Nature 241:465-467

Dorson M, Torchy C, Chilmonczyk P, de Kinkelin P, Michel C (1984) A rhabdovirus pathogenic for perch, Perca fluviatilis L.: isolation and preliminary study. J Fish Dis 7:241-245

Fijan N, Petrinec Z, Sulimanovic D, Zwillenberg LO (1971) Isolation of the viral causative agent from the acute form of infectious dropsy of carp. Vet Arhiv Zagreb 41:125-135

Frerichs GN (1989) Rhabdoviruses of fishes. In: Ahne W, Kurstak E (eds) Viruses of lower vertebrates. SpringerVerlag, Berlin, p 317-332

Frerichs GN, Millar SD, Roberts RJ (1986) Ulcerative rhabdovirus in fish in south-east Asia. Nature 322:216

Granzow H, Weiland F, Fichtner D, Enzmann PJ (1997) Studies of the ultrastructure and morphogenesis of fish pathogenic viruses grown in cell culture. J Fish Dis 20:1-10

Gui JF, Lane WS, Fu XD (1994) A serine kinase regulates intracellular localization of splicing factors in the cell cycle. Nature 369:678-682

Jensen MH (1963) Preparation of fish tissues for virus research. Bull Off Int Epizoot 59:131-134

Jensen NJ, Bloch B, Larsen JL (1979) The ulcus-syndrome in cod (Gadus morhua): III. A preliminary virological report. Nord Vetmed 31:436-442

Jiang YL, Zhang QY, Liu H, LI Y, Li ZQ (1995) Study on cause of infectious diseases of penaeid shrimp in China. Acta Hydrobiol Sin 19(2):186-187 (Chinese with English abstract)

Kasornchandra J, Lannan CN, Rohovec JS, Fryer JL (1991) Characterization of a rhabdovirus isolated from the snakehead fish (Ophicephalus striatus). In: Fryer L (ed) Proceedings second international symposium on viruses of lower vertebrates. Oregon State University, Corvallis, p 175-182 
Kasornchandra J, Engelking HM, Lannan CN, Rohovec JS, Fryer JL (1992) Characteristics of three rhabdoviruses from snakehead fish Ophicephalus striatus. Dis Aquat Org 13:89-94

Kimura T, Yoshimizu M, Gorie S (1986) A new rhabdovirus isolated in Japan from cultured hirame (Japanese flounder) Paralichthys olivaceus and ayu Plecoglossus altivelis. Dis Aquat Org 1:209-217

Leong JC (1995) Molecular biological tools to detect fish pathogens. J Fish Biol 47(Suppl A):61-75

Lightner DV, Redman RM (1998) Strategies for the control of viral diseases of shrimp in the Americas. Fish Pathol 33(4): 165-180

Lilley JH, Frerichs GN (1994) Comparison of rhabdoviruses associated with epizootic ulcerative syndrom (EUS) with respect to their structural proteins, cytopathology and serology. J Fish Dis 17:513-522

Malsberger RG, Lautenslager G (1980) Fish viruses: rhabdovirus isolated from a species of the family Cichlidae. Fish Health News 9:1-2

Marty GD, Freiberg EF, Meyers TR, Wilcock J, Farver TB, Hinton DE (1998) Viral hemorrhagic septicemia virus, Ichthyophonus hoferi, and other causes of morbidity in Pacific herring Clupea pallasi spawning in Prince William Sound, Alaska, USA. Dis Aquat Org 32:15-40

Meyers TR, Winton JR (1995) Viral hemorrhagic septicemia virus in North America. Annu Rev Fish Dis 5:3-24

Meyers TR, Short S, Lipson K, Batts WM, Winton JR, Wilcock J, Brown E (1994) Association of viral hemorrhagic septicemia virus with epizootic hemorrhages of the skin in Pacific herring Clupea harengus pallasi from Prince William Sound and Kodiak Island, Alaska, USA. Dis Aquat Org 19:27-37

Miller TA, Rapp J, Wastlhuber U, Hoffmann RW, Enzmann PJ (1998) Rapid and sensitive reverse transcriptase-polymerase chain reaction based detection and differential diagnosis of fish pathogenic rhabdoviruses in organ samples and cultured cells. Dis Aquat Org 34:13-20

Munday BL, Owens L (1998) Viral diseases of fish and shellfish in Australian mariculture. Fish Pathol 33(4):193-200

Murphy FA, Fauquet CM, Bishop DHL, Ghabrial SA, Jarvis AW, Martelli GP, Mayo MA, Summers MD (eds) (1995) Virus taxonomy, classification and nomenclature of viruses, Sixth Report of the International Committee on Taxonomy of Viruses. Springer-Verlag, Wien

Nadala ECB Jr, Tapay LM, Loh PC (1997) Yellow-head virus: a rhabdovirus-like pathogen of penaeid shrimp. Dis Aquat Org 31:141-146

Nakajima K, Inouye K, Sorimachi M (1998) Viral diseases in cultured marine fish in Japan. Fish Pathol 33(4):181-188

Osadchaya YF, Nakonechnaya MG (1981) Rhabdovirus salmonis, the cause of a new disease in rainbow trout, Salmo gairdneri. J Ichthyol 21:113-121

Reed JL, Muench H (1938) A simple method of estimating fifty percent endpoint. Am J Hyg 27:493-497

Editorial responsibility: Jo-Ann Leong,

Corvallis, Oregon, USA
Rodgers CJ, Furones MD (1998) Disease problems in cultured marine fish in the Mediterranean. Fish Pathol 33(4): $157-164$

Rovozzo GC, Burke CN (1973) A manual of basic virological techniques. Prentice-Hall, Englewood Cliffs, NJ

Sano T (1976) Viral diseases of cultured fishes in Japan. Fish Pathol 10:221-226

Sano T, Nishimura T, Okamoto N, Fukuda H (1977) Studies on viral diseases of japanese fishes. VII. A rhabdovirus isolated from European eel Anguilla anguilla. Bull Jpn Soc Sci Fish 43:491-495

Shchelkunov IS, Shchelkunova TI (1989) Rhabdovirus carpio in herpivorous fishes: isolation, pathology and comparative susceptibility of fishes. In: Ahne W, Kurstak E (eds) Viruses of lower vertebrates. Springer-Verlag, Berlin, p 333-348

Sohn SG, Park MA (1998) Viral diseases of cultured marine fish and shrimp in Korea. Fish Pathol 33(4):189-192

Spann KM, Cowley JA, Walker PJ, Lester RJG (1997) A yellow-head-like virus from Penaeus monodon cultured in Australia. Dis Aquat Org 31:169-179

Wolf K (1988) Fish viruses and fish viral diseases. Cornell University Press, Ithaca, NY

Yue P, Chen Y (1998) China red data book of endangered animals - pisces. Science Press, Beijing, p 57-60

Zhang QY (1997) Studies on viral diseases of special aquaculture animals. PhD thesis, Institute of Hydrobiology, Chinese Academy of Sciences (Chinese with English abstract)

Zhang QY, Li ZQ (1999) Three different viruses observed from the tissues of diseased mandarin fish Siniperca chuatsi. Chin Sci Bull 44(5):437-441

Zhang QY, Li ZQ, Jiang YL, Liang SC, Gui JF (1996a) Preliminary studies on virus isolation and cell infection from disease frog Rana grylio. Acta Hydrobiol Sin 20:390-392 (Chinese with English abstract)

Zhang QY, Li ZQ, Gui JF (1996b) Studies on the viral pathogens from the special aquaculture animals and the prevention biotechnology in China. In: Proceedings of Sino-American Symposium on Agricultural Research and Development in China. China Agriculture Press, Beijing, p 168-174 (Chinese with English abstract)

Zhang QY, Li ZQ, Jiang YL, Liang SC, Gui JF (1997) Discovery of virus pathogen from soft-shelled turtle Trionyx sinesis. Chin Sci Bull 42(6):503-506

Zhang QY, Jiang YL, Li Y, Li ZQ (1998) Isolation and characterization of nucleocapsids and enveloped virions of Penaeus monodon baculovirus. Acta Hydrobiol Sin 22(Suppl): $1-5$

Zhang QY, Li ZQ, Gui JF (1999a) Cellular pathological studies on death of soft-shelled turtles induced by virus infection. Virol Sin 14(1):50-54 (Chinese with English Abstract)

Zhang QY, Li ZQ, Gui JF (1999b) Studies on morphogenesis and cellular interactions of Rana grylio virus (RGV) in an infected fish cell line. Aquaculture 175:185-197

Submitted: April 20, 1999; Accepted: March 16, 2000

Proofs received from author(s): July 4, 2000 